\title{
Physiological Studies on the Pneumococcal Forssman Antigen: a Choline-containing Lipoteichoic Acid
}

\author{
By EVE B. BRILES AND A. TOMASZ \\ The Rockefeller University, New York, N.Y. I002 I, U.S.A.
}

(Received 25 July 1974; revised I 8 September 1974)

\begin{abstract}
The cell concentration and possible biological activities of the pneumococcal Forssman (F) antigen (membrane lipoteichoic acid) were examined in a number of physiological situations. In test tube cultures of pneumococci the concentration of the Forssman antigen per bacterium showed no significant fluctuations within a typical culture cycle. Purified $\mathrm{F}$ antigen had no effect on the activation of pneumococci to competence for genetic transformation, DNA mediated genetic transformation or adsorption of the pneumococcal phage Dp-I to bacteria. Pneumococci grown in the presence of different amino alcohols (ethanolamine, $N$-monomethylethanolamine, or choline) exhibit differences with regard to both their ability to stimulate heterophile (haemolytic) antibody production in rabbits and in their ability to bind such antibodies. Choline-grown bacteria seem to cross-react with sheep red blood cells better than do the analogue-grown bacteria.
\end{abstract}

\section{INTRODUCTION}

Pneumococci have a nutritional requirement for choline; this amino alcohol seems to be a unique structural component of the teichoic acids of this bacterium (Tomasz, 1967). About 80 to $85 \%$ of cell choline is part of the cell-wall teichoic acids (Mosser \& Tomasz, 1970) while about $15 \%$ can be localized in the pneumococcal heterophile (Forssman) antigen, which is a membrane lipoteichoic acid (Briles \& Tomasz, 1973). While these two teichoic acids seem to have much in common as far as chemical composition and primary structure is concerned (Goebel, Shedlovsky, Lavin \& Adams, 1943; Fujiwara, 1967; Brundish \& Baddiley, 1968), they are distinct in several respects: the major (wall) teichoic acid is covalently linked to the cell wall and is the carrier of the C-specific antigen-determinants (Mosser \& Tomasz, 1970; Goebel et al. 1943; Brundish \& Baddiley, 1968). In contrast, the lipoteichoic acid seems to be located in the plasma membrane (or between membrane and wall) (Briles \& Tomasz, 1973); it is the carrier of an immunological determinant that crossreacts with the Forssman series of mammalian surface antigens. Unlike the wall teichoic acid, the lipoteichoic acid contains strongly (possibly covalently) bound fatty acids (Goebel et al. 1943; Fujiwara, 1967; Brundish \& Baddiley, 1968).

Recently we described some biochemical properties of the pneumococcal $F$ antigen (Briles \& Tomasz, 1973) and presented evidence that the F antigen (lipoteichoic acid) is not a precursor to the wall teichoic acid (Briles \& Tomasz, unpublished). In this communication we report on physiological experiments with this lipoteichoic acid. 


\section{METHODS}

Strain R36A of Diplococcus pneumoniae was used in all the studies. Details of several of the methods used can be found in the published literature. These methods include: growth of pneumococci (Tomasz, I966); assay of viable bacteria and genetic transformants (Hotchkiss, I957); activation of bacteria to competence (Tomasz, I966); growth of bacteria in ethanolamine (EA)-containing media (Mosser \& Tomasz, 1970); preparation of transforming DNA (Hotchkiss, I957); and assay of the pneumococcal phage Dp-r (McDonnell, Ronda-Lain \& Tomasz, I974).

Sheep red blood cells were obtained either from freshly-drawn whole sheep's blood preserved in sterile Alsever's solution (Kabat \& Mayer, 1967), or commercially from Microbiological Associates.

Guinea-pig complement was obtained from Microbiological Associates in lyophilized form; upon reconstitution, it was absorbed with sheep red blood cells (Kabat \& Mayer, 1967) and stored at $-20^{\circ} \mathrm{C}$. Complement prepared in this way is active for I month. Titration of complement was performed according to the method of Kabat \& Mayer (1967).

Anti-pneumococcal F-antigen sera were produced in New Zealand Red (NZR) rabbits. Vaccine was prepared in the following manner: pneumococci were grown in $910 \mathrm{ml}$ medium, harvested at mid-log phase by centrifugation at $0{ }^{\circ} \mathrm{C}$, washed once with $0.86 \% \mathrm{NaCl}$ at $0{ }^{\circ} \mathrm{C}$, resuspended to $20 \mathrm{ml}$ with $0.86 \% \mathrm{NaCl}$, heat-killed at 60 to $70^{\circ} \mathrm{C}$ for $20 \mathrm{~min}$, and stored in $3 \mathrm{ml}$ portions at $-20^{\circ} \mathrm{C}$. Young rabbits $(5$ to $8 \mathrm{lb}$ ) whose pre-immune sera showed 20 $\mathrm{AbH}_{50} / \mathrm{ml}$ or less $\left(\mathrm{AbH}_{50}\right.$ being the amount of antibody that lyses $50 \%$ of red cells in the presence of excess complement) were immunized by a course of intravenous injections consisting of from 0.5 to $\mathrm{I} \cdot 0 \mathrm{ml}$ of undiluted vaccine on each of days $\mathrm{I}, 2,4$ and 7 ; blood was drawn for serum on or about day $\mathrm{I}$ 2. Endogenous complement was inactivated at $56{ }^{\circ} \mathrm{C}$ for I 5 min before storage of the antisera at $-20^{\circ} \mathrm{C}$. Haemolytic antibody was titrated by the method of Kabat \& Mayer (1967). Antiserum obtained from a single rabbit at a single bleeding, designated NZRA, was used for all routine determinations of $F$ activity except as noted in the text.

All complement-mediated immunological assays were performed in barbital-buffered saline, $\mathrm{pH} 7 \cdot 5$, containing $5 \times \mathrm{IO}^{-4} \mathrm{M}-\mathrm{MgCl}_{2}$ and $\mathrm{I} \cdot 7 \times \mathrm{IO}^{-4} \mathrm{M}^{-} \mathrm{CaCl}_{2}$. This diluent was prepared as a fivefold concentrate according to the procedure of Kabat \& Mayer (I967), and was stored at $5{ }^{\circ} \mathrm{C}$.

The $\mathrm{F}$ antigen and $\mathrm{C}$-carbohydrate were isolated by procedures adapted from the method of Goebel et al. (1943). The essence of this method is as follows. The C-carbohydrate is solubilized during autolysis, whereas the $\mathrm{F}$ antigen remains associated with the particulate detritus. The $\mathrm{F}$ antigen can be solubilized from the detritus after a sequence of proteolytic and defatting steps. Details of the isolation procedure have been published elsewhere (Briles \& Tomasz, 1973).

$\mathrm{F}$ antigen was titrated on the basis of its Forssman cross-reactivity by means of a haemolysis-inhibition assay performed in the following manner: a dilution of rabbit antipneumococcal F-antigen serum containing $7 \mathrm{AbH}_{50} / \mathrm{ml}$ was added to an equal volume of serially-diluted test sample, and incubated at room temperature for I h. A $0.5 \mathrm{ml}$ portion of this was then added to $0.5 \mathrm{ml}$ of a suspension of sheep red cells containing $\mathrm{I} \times 10^{9} \mathrm{cells} / \mathrm{ml}$ (cell density determined by the laking method of Kabat \& Mayer, I967) at $0^{\circ} \mathrm{C}$; this was incubated at $37^{\circ} \mathrm{C}$ for $15 \mathrm{~min}$, then chilled in an ice-water bath. Each sample then received $0.25 \mathrm{ml}$ of a dilution of prepared guinea-pig complement containing I $2 \mathrm{C}^{\prime} \mathrm{H}_{50} / \mathrm{ml}\left(\mathrm{C}^{\prime} \mathrm{H}_{50}\right.$ being that amount of complement that lysis $50 \%$ of sensitized red cells), and was incubated 
at $37^{\circ} \mathrm{C}$ for $15 \mathrm{~min}$. The lytic reaction was terminated by chilling the samples in ice water and immediately adding $2.5 \mathrm{ml}$ of ice cold saline-citrate (4 parts $0.15 \mathrm{M}-\mathrm{NaCl}$ to I part $0.075 \mathrm{M}$-sodium citrate). The extent of haemolysis was determined by measuring the extinction of the supernatant at 54I $\mathrm{nm}$ with a Zeiss PMQ II spectrophotometer. The number of units of F-antigen activity per $0.5 \mathrm{ml}$ of a sample was arbitrarily defined as that factor of dilution which results in $50 \%$ inhibition of haemolysis under the assay conditions described.

All other immunological procedures were performed as described by Kabat \& Mayer (1967).

Competent and incompetent bacteria. Competent and incompetent cultures of pneumococci were prepared according to published procedures (Tomasz, I966). The level of competence of the cultures was tested by transformation with exogenous pneumococcal DNA bearing a streptomycin-resistance marker. The bacteria were heat-killed at 65 to $90{ }^{\circ} \mathrm{C}$ for Io min to inactivate the endogenous haemolysins, and stored at $-20{ }^{\circ} \mathrm{C}$ before use. The F-antigen assays were performed on whole (thawed) bacteria.

Determination of F-antigen content per bacterium as a function of growth. Pneumococci were grown up in $400 \mathrm{ml}$ of $\mathrm{C}$ medium (Tomasz, 1966), from a $10 \mathrm{ml}$ inoculum at midlogarithmic phase. Growth of the culture was monitored with a Coleman Nephelometer (Nephelo-spectrophotometer). At various times during growth of the culture, known sample volumes were removed; the samples were harvested at $0^{\circ} \mathrm{C}$ by centrifugation, resuspended in $5 \mathrm{ml}$ of saline, heated to $90^{\circ} \mathrm{C}$ for $10 \mathrm{~min}$, and stored at $-20^{\circ} \mathrm{C}$.

The thawed saline suspensions were standardized by appropriate dilution with saline to suspensions whose bacterial densities corresponded to 800 Nephelos units $\left(2 \times 10^{8}\right.$ cells $\left./ \mathrm{ml}\right)$. Each standardized suspension was then assayed for $\mathrm{F}$ antigen by the haemolysis-inhibition assay (twofold serial dilutions of the suspensions were employed).

\section{RESULTS}

\section{$F$-antigen content of pneumococci as a function of growth}

To determine whether or not the F-antigen content of pneumococci varies significantly as a function of growth, a single growing culture (in C medium) was sampled periodically during the logarithmic and early stationary phases of growth, and the number of F-antigen units per $10^{8}$ bacteria was determined for each sample. Growth was logarithmic until the culture reached 800 Nephelos units, whereupon the bacteria entered stationary phase. The results of this experiment, summarized in Table I, show no significant differences in Fantigen content per bacteria at the growth stages tested.

\section{$F$-antigen content of competent and incompetent bacteria}

A comparison was made between pneumococci which are physiologically capable of becoming genetically transformed by exogeneous DNA ('competent' cells) and those which are not ('incompetent' cells).

As can be seen from Table 2, no significant difference was observed, with respect to Fantigen content per bacterium, between competent and incompetent cultures.

\section{Hypothetical biological activities of the F antigen}

Table 2 summarizes the results of a series of experiments in which a possible effect of $F$ antigen was tested on several physiological phenomena, including activation to competence for genetic transformation, transformation by genetically marked DNA, and survival of the biological activity of bacteriophage Dp-I. No effect was found on any of these phenomena. 
Table I. Stability of F-antigen concentration in bacteria during culture growth

$\begin{array}{ccc}\begin{array}{c}\text { Sampling time } \\ \text { (min after first sample) }\end{array} & \begin{array}{c}\text { Culture concn } \\ \text { (bacteria/ml) }\end{array} & \begin{array}{c}\mathrm{F} \text { antigen } \\ \text { (units } / 10^{8} \text { bacteria) }\end{array} \\ 0 & 3.15 \times 10^{7} & 7 \cdot 0 \\ 40 & 5.6 \times 10^{7} & 8.5 \\ 80 & 8.1 \times 10^{7} & 12 \cdot 0 \\ 100 & 1 \cdot 1 \times 10^{8} & 8 \cdot 5 \\ 120 & 1.4 \times 10^{8} & 8 \cdot 5 \\ 140 & 1 \cdot 7 \times 10^{8} & 7 \cdot 5 \\ 160 & 2.1 \times 10^{8} & 7 \cdot 0 \\ 180 & 2.0 \times 10^{8} & 6.0 \\ 200 & 1.8 \times 10^{8} & 6.0\end{array}$

Table 2. The effect of $F$ antigen on some physiological phenomena of pneumococci

$\mathrm{F}$ antigen content (units $/ 10^{8}$ cells)

Competent $\left(\mathrm{I} \times 10^{7}\right.$ strep $^{\mathrm{R}}$ transformants $/ 10^{8}$ bacteria)

Incompetent $\left(<300\right.$ strep $^{R}$ transformants $/ 10^{8}$ bacteria)

$3 \cdot 2,3 \cdot 8^{*}$

$3 \cdot 2,3 \cdot 0^{*}$

Number of transformants $/ \mathrm{ml}$

$\mathrm{R} 36 \mathrm{~A}$ ( $\mathrm{I} \times 10^{7}$ bacteria $/ \mathrm{ml}$; incompetent)+ activator

$\mathrm{R} 36 \mathrm{~A}\left(\mathrm{I} \times \mathrm{IO}^{7}\right.$ bacteria $/ \mathrm{ml}$; incompetent $)+$ activator $+\mathrm{F}$ antigen $(20 \mu \mathrm{g} / \mathrm{ml})$

R36A ( $\times 10^{8}$ bacteria $/ \mathrm{ml}$; competent $)+$ DNA

R36A ( $1 \times 10^{8}$ bacteria $/ \mathrm{ml}$; competent $)+$ DNA + F antigen $(20 \mu \mathrm{g} / \mathrm{ml})$

$0.8 \times 10^{6}$

$0.9 \times 10^{6}$

$1.0 \times 10^{7}$

Virus titre (p.f.u./ml)

Dp-I, $37^{\circ} \mathrm{C}$ for $30 \mathrm{~min}$

Dp-r $+\mathbf{F}$ antigen $(20 \mu \mathrm{g} / \mathrm{ml}), 37^{\circ} \mathrm{C}$ for $30 \mathrm{~min}$

$\mathrm{I} \cdot \mathrm{I} \times \mathrm{IO}^{7}$

$3.0 \times 10^{8}$

$3.1 \times 10^{8}$

* Results of two separate trials.

Table 3. Titres of heterophile antisera elicited by pneumococci grown on various amino alcohols

Vaccine type

MEA-grown bacteria

EA-grown bacteria

Choline-grown bacteria
Rabbit

NZR-D

NZR-C

NZR-A

NZR-MA

NZR-MB

NZR-MC

NZR-JI *

NZR-J2*
Titre $\left(\mathrm{AbH}_{50} / \mathrm{ml}\right)$

$$
400
$$

520

5000

6000

3500

10000

700

4000

* These rabbits received no injections on day 4 ; titres were deterwined for day 17 bleedings.

Elicitation of heterophile antibodies by choline- and analogue-grown cells

Heterophile antisera were produced in rabbits by intravenous injection of vaccines prepared from pneumococci grown with either choline, ethanolamine (EA) or N-monomethylethanolamine (MEA) as their sole source of amino alcohol. The haemolytic titres obtained in each case are listed in Table 3. Although the number of rabbits involved in this comparison is small, a pattern emerges suggesting that the quantitative yield of heterophile (sheep-haemolytic) antibody elicited by pneumococci is dependent on the amino alcohol composition of the bacteria: choline-grown bacteria seem to elicit haemolytic titres which exceed those titres induced by analogue-grown bacteria by roughly an order of magnitude. 


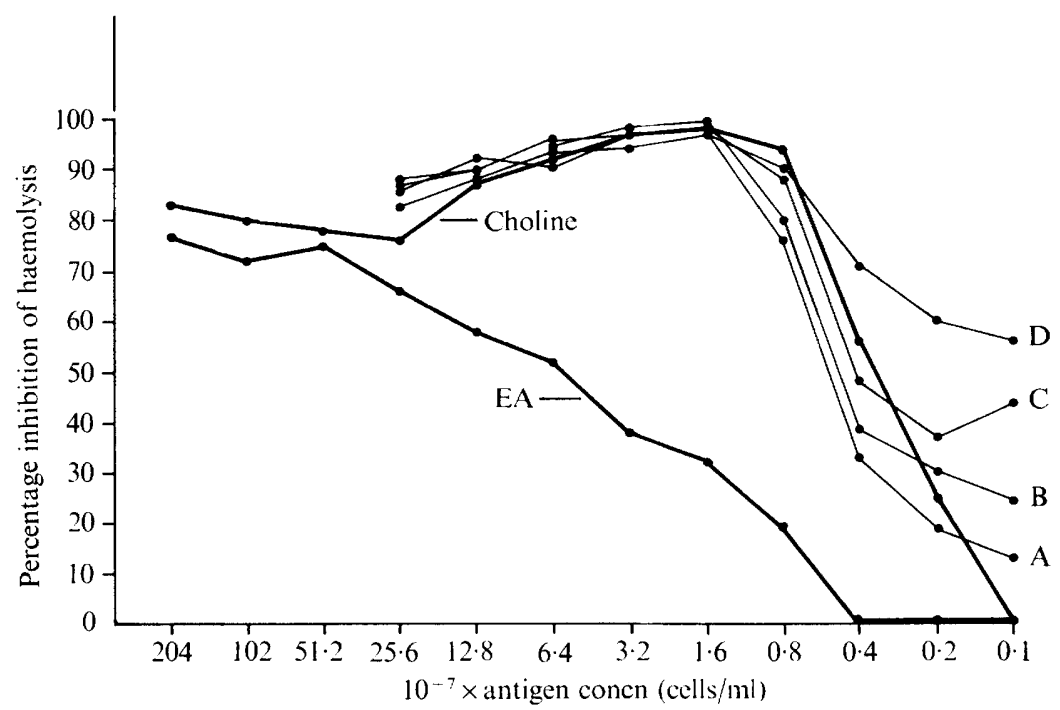

Fig. I. Titration curves for F-antigen activity of sonicated pneumococcal extracts. Extracts were assayed using NZR-A antiserum (directed against choline-grown bacteria). Indicated curves are for choline-grown bacteria ('Choline'), ethanolamine-grown bacteria ('EA'), and mixtures; the mixtures contained sonicated choline-grown bacteria in the concentrations indicated along the axis, plus a constant amount of sonicated EA-grown bacteria. In mixture A, this was $0.4 \times 10^{7}$ cells of EA-grown pneumococci $/ \mathrm{ml}$; in $\mathrm{B}, 0.8 \times 10^{7}$ cells $/ \mathrm{ml}$; in $\mathrm{C}, \mathrm{I} .6 \times 10^{7} \mathrm{cells} / \mathrm{ml}$; in D, $3.2 \times 10^{7}$ cells $/ \mathrm{ml}$.

\section{Cross-reactivity between choline- and analogue-grown bacteria}

Preliminary experiments suggested that the ability of analogue-grown bacteria to inhibit the haemolysis of sheep red blood cells by NZR-A serum (the haemolytic antiserum produced in response to choline-grown bacteria) was either poor or non-existent. This seemed to be true for both whole heat-killed bacteria and for sonicated preparations.

An example of such a result is presented in Fig. I. The slope in the case of the cholinecontaining bacteria is much steeper than in the case of the EA-containing bacteria, indicating that the choline-grown bacteria bind much more strongly to the NZR-A haemolytic antibody than do the EA-grown bacteria. The choline-grown bacteria also exhibit a 20-fold higher titre (based on the point of $50 \%$ inhibition of haemolysis) than the ethanolamine EA-grown bacteria, but this difference may be an exaggerated one due to the difference in antibody binding. The titration curves obtained for the mixtures (curves A, B, C and D) indicate that the ethanolamine-containing material does not interfere with the normal behaviour of the choline-containing material in this assay.

Table 4 summarizes an experiment in which choline- and analogue-grown pneumococci were tested for F-antigen activity using haemolytic antisera produced in response to choline-grown, EA-grown, and MEA-grown bacteria (NZR-A, NZR-C and NZR-D, respectively; see Table 3). Both the F-antigen titres (based on $50 \%$ inhibition of haemolysis) and slopes of the titration curves are tabulated. The higher the numerical value of the slope, the steeper the curve and thus the stronger the binding between the antigen and the antibody. Since the slopes were determined for the part of the curve around $50 \%$ inhibition of haemolysis, no slopes could be determined for those curves which did not intersect the $50 \%$ inhibition level at the concentrations tested. Both whole bacteria and sonicated preparations 


\section{Table 4. Differences between heterophile antisera prepared against pneumococci grown on various amino alcohols}

The titres are the numbers of F-activity units observed $/ 5 \times 10^{7}$ bacteria or their equivalent (in the case of sonicates). Slopes are given as percentage changes of haemolysis inhibition per twofold dilution of antigen, divided by 100 .

\begin{tabular}{|c|c|c|c|c|c|c|}
\hline \multirow{3}{*}{$\begin{array}{l}\text { Pneumococci } \\
\text { tested for } \\
\text { haemolysis } \\
\text { inhibition }\end{array}$} & \multicolumn{6}{|c|}{ Antiserum directed against: } \\
\hline & \multicolumn{2}{|c|}{ Choline bacteria } & \multicolumn{2}{|c|}{ EA-bacteria } & \multicolumn{2}{|c|}{ MEA-bacteria } \\
\hline & Titre & Slope & Titre & Slope & Titre & Slope \\
\hline \multicolumn{7}{|l|}{ Whole bacteria } \\
\hline Choline-grown & $4 \cdot 7$ & 0.60 & $I \cdot 25$ & 0.64 & $5 \cdot 0$ & 0.44 \\
\hline EA-grown & 0.29 & $0 \cdot 19$ & 0.32 & 0.50 & $0 \cdot 80$ & 0.50 \\
\hline MEA-grown & $\ll 0.2$ & - & $0.5 \mathrm{I}$ & 0.60 & 0.24 & 0.55 \\
\hline \multicolumn{7}{|l|}{ Sonicated bacteria } \\
\hline Choline-grown & $17 \cdot 0$ & 0.34 & $9 \cdot 0$ & 0.18 & $\gg 6 \cdot 4$ & - \\
\hline EA-grown & $<0.2$ & - & $2 \cdot 4$ & 0.20 & $6 \cdot 4$ & - \\
\hline MEA-grown & $<0.2$ & - & $4 \cdot 5$ & 0.22 & $>6.4$ & - \\
\hline
\end{tabular}

were tested for antigenicity. In general, sonication increased the observed F-antigen titre of a preparation, while decreasing the slope of the titration curve. This is reasonable, since sonication would be expected to increase the number of antigen-bearing particles (and possibly expose antigens which may be sequestered in whole bacteria), while decreasing the number of antigenic sites per particle (hence decreasing the avidity of binding of the antibody). Sonication did not boost the titres of the analogue-grown bacteria disproportionately with respect to the choline-grown bacteria.

From the slope values it can be seen that the haemolytic antiserum directed against choline-grown bacteria binds relatively poorly to EA-grown bacteria, and even more poorly (if at all) to those grown on MEA. However, the haemolytic antisera directed against the analogue-grown bacteria seem to bind with equal avidity to analogue-grown and cholinegrown bacteria.

\section{DISCUSSION}

Although it is believed that all Gram-positive bacteria contain membrane lipoteichoic acids, the functions of these polymers are entirely unknown. Heptinstall, Archibald \& Baddiley (1970) have proposed that lipoteichoic acids serve to bind divalent cations, thereby maintaining the proper ionic environment for membrane functions. Mauck \& Glaser (1972) have isolated a lipoteichoic acid from Bacillus subtilis which serves as an acceptor for glycerol phosphate residues (from CDP-glycerol) in the presence of a particleassociated teichoic synthetase; they propose that the teichoic acid chain is assembled in vivo at the membrane, whereupon the completed chain is transferred from its lipid carrier to the wall position. Interestingly, Glaser and his colleagues have detected such lipoteichoic acid carriers in a variety of bacteria; they invariably contained glycerol and phosphate and their carrier functions were interchangeable among a number of the different species. Pneumococcal lipoteichoic acid was found to be inactive in this test system (Fiedler \& Glaser, 1974). We have not tested our F-antigen preparations for the possible presence of polyglycerophosphate. Recent pulse-chase studies showed that, at least in pneumococci, the lipoteichoic acid (F antigen) is not a precursor to the wall teichoic acid (Briles \& Tomasz, unpublished).

The observation that the amino alcohol constitution of the $\mathrm{F}$ antigen affects its Forssman cross-reactivity warrants comment. Pneumococci grown with choline analogues (EA, MEA) 
as sole amino alcohol source are significantly different from choline-grown bacteria in several respects: they are unable to separate completely after division and thus grow in long chains; they are unable to undergo genetic transformation; and they no longer are capable of autolysis or bile-solubilization (Tomasz, I968). EA-grown bacteria are resistant to the recently isolated pneumococcal bacteriophage Dp-I (McDonnell et al. I974) and such bacteria show a completely dose-independent resistance to a large number of bacteriolytic antibiotics.

Most, if not all, of these physiological effects are probably consequences of two biochemical defects that one can recognize in EA-grown bacteria: (i) the cell walls of such pneumococci are resistant to the endogenous muralytic enzyme (an $\mathrm{N}$-acetylmuramyl-Lalanine amidase) (Mosser \& Tomasz, 1970) and EA-grown bacteria (ii) contain an abnormal (low molecular weight and low catalytic activity) form of the muralytic amidase (Tomasz \& Westphal, 197I).

In the case of the $\mathrm{F}$ antigen, the ability of pneumococci to elicit a heterophile response per se is independent of the amino alcohol constituent of the bacteria, suggesting that the amino alcohol residues are not critical for the Forssman determinant; this conclusion is supported by the fact that the mammalian Forssman hapten contains no amino alcohol residues (Ando \& Yamakawa, 1970). However, the choline-grown bacteria elicit antibodies which bind only poorly to analogue-grown bacteria, while the analogue-grown bacteria elicit antibodies which bind well to choline-grown bacteria; also, the choline-grown bacteria elicit more heterophile antibodies in rabbits than do analogue-grown bacteria. It seems as if the Forssman cross-reactive determinant of the analogue-grown bacteria is present in the choline-grown bacteria, but that there is some further 'determinant' in the choline-grown bacteria which is unavailable in the analogue-grown bacteria.

These investigations have been supported by a grant from the National Institute of Health, U.S.A.

\section{REFERENCES}

Ando, S. \& YamaKawa, T. (1970). On the oligosaccharide of Forssman-active sheep red cell glycolipid. Chemistry and Physiology of Lipids 5, 91-95.

Briles, E. B. \& Tomasz, A. (1973). Pneumococcal Forssman antigen, a choline containing lipoteichoic acid. Journal of Biological Chemistry 248, 6394-6397.

Brundish, D. E. \& Baddiley, J. (1968). Pneumococcal C-substance, a ribitol teichoic acid containing choline phosphate. Biochemical Journal I10, 573-582.

FiedLer, F. \& GLASER, L. (1974). The synthesis of polyribitol phosphate. Journal of Biological Chemistry 249 , 2690-2695.

FujIWARA, M. (1967). The Forssman antigen of pneumococcus. Japanese Journal of Experimental Medicine 37, 581-59I.

Goebel, W. H., Shedlovsky, T., Lavin, G. I. \& Adams, M. H. (I943). The heterophile antigen of pneumococcus. Journal of Biological Chemistry 148, I-I 5 .

Heptinstall, S., Archibald, A. R. \& Baddiley, J. (I970). Teichoic acids and membrane function in bacteria. Nature, London 225, 519-52 I.

Hotchкiss, R. D. (1957). Isolation of sodium deoxyribonucleate in biologically active form from bacteria. In Methods in Enzymology, vol. 3, p. 692. Edited by S. P. Colowick and N. O. Kaplan. New York: Academic Press.

Kabat, E. A. \& Mayer, M. M. (1967). Experimental Immunochemistry, 2nd edn. Springfield, Illinois: Charles C. Thomas.

MaUCK, J. \& Glaser, L. (1972). An acceptor-dependent polyglycerolphosphate polymerase. Proceedings of the National Academy of Sciences of the United States of America 69, 2386-2390.

McDonnell, M., Ronda-Lain, C. \& Tomasz, A. (1974). Diplophage I: a bacteriophage of Diplococcus pneumoniae. Virology (in the Press). 
Mosser, J. L. \& Tomasz, A. (I970). Choline-containing teichoic acid as a structural component of pneumococcal cell wall and its role in sensitivity to lysis by an autolytic enzyme. Journal of Biological Chemistry 245, 287-298.

Tomasz, A. (1966). A model for the mechanism controlling the expression of competent state in pneumococcus cultures. Journal of Bacteriology 9r, 1050-1061.

Tomasz, A. (1967). Choline in the cell wall of a bacterium: novel type of polymer-linked choline in pneumococcus. Science, New York 157, 694-697.

Tomasz, A. (1968). Biological consequences of the replacement of choline by ethanolamine in the cell wall of pneumococcus: chain formation, loss of transformability, and loss of autolysis. Proceedings of the National Academy of Sciences of the United States of America 59, 86-93.

Tomasz, A. \& WeSTPHAL, M. (197I). Abnormal autolytic enzyme in a pneumococcus with altered teichoic acid composition. Proceedings of the National Academy of Sciences of the United States of America 68, $2627-2630$. 